\title{
SYNTHESIS, CHARACTERIZATION AND THERMAL BEHAVIOUR OF SOLID STATE COMPOUNDS OF 2-CHLOROBENZYLIDENEPYRUVATE WITH TRIVALENT ALUMINIUM, GALLIUM, INDIUM AND SCANDIUM METALS.
}

\author{
G. BANNACH ${ }^{1 ;}$ E. SCHNITZLER ${ }^{2 ;}$ M. IONASHIRO ${ }^{1}$
}

\begin{abstract}
Solid state compounds M-2-Cl-BP, where 2-Cl-BP is 2-chlorobenzylidenepyruvate and $\mathrm{M}$ represents $\mathrm{Al}, \mathrm{Ga}$, In, and Sc were prepared. X-ray powder diffractometry, infrared spectroscopy and simultaneous thermogravimetry-differential thermal analysis (TG-DTA), have been used to characterize and to study the thermal behavior of these compounds. The results provided information concerning the stoichiometry, crystallinity, thermal stability and thermal decomposition of the compounds.
\end{abstract}

Keywords: 2-chlorobenzylidenepyruvate, characterization, thermal behaviour.

\section{Introduction}

Preparation and investigation of several metal ion complexes with 4dimethylaminobenzylidenepyruvate (DMBP), 2choro-4-dimethylaminobenzylidenepyruvate (2-ClDMBP), 4-metoxybenzylidenepyruvate (4-MeO$\mathrm{BP})$, cynnamylidenepyruvate $(\mathrm{CP})$ have been investigated in aqueous solution $[5-8,13,17]$.

In the solid state, several metal-ion complexes with DMBP, 4-MeO-BP and CP, have also been prepared and investigated by using thermoanalytical techniques (TG, DTA, DSC), elemental analysis and $\mathrm{X}$-ray powder diffractometry. The establishment of the stoichiometry, thermal stability as well as the thermal decomposition has been the main purposes of the aforementioned studies.

In this work, solid-state compounds of the trivalent ions with 2-chlorobenzylidenepyruvate, 2- $\mathrm{Cl}-\mathrm{C}_{6} \mathrm{H}_{4}-\mathrm{CH}=\mathrm{CH}-\mathrm{COCOO}-(2-\mathrm{Cl}-\mathrm{BP})$ were prepared. The compounds were investigated by means of X-ray powder diffractometry, infrared spectroscopy and simultaneous TG-DTA. The results of the present study improve the knowledge on these compounds including their thermal stability and thermal decomposition.

\section{Experimental}

The sodium salt of 2-chlorobenzylidenepyruvic acid, was prepared following the same procedure described in the literature [14]. Scandium and gal-

\footnotetext{
${ }^{1}$ Departamento de Química Analítica - Instituto de Química - UNESP CEP 14801-970 - Araraquara - SP - Brasil.

${ }^{2}$ Departamento de Química - UEPG - CEP 84030 - Ponta Grossa - PR - Brasil.
} 
lium nitrates were prepared from the scandium oxide and metallic gallium by treatment with concentrated nitric acid. The resulting solutions were transferred to a volumetric flask, and their $\mathrm{pH}$ values were adjusted to 5 and 3, respectively, by the use of a solution of diluted nitric acid solution. Aqueous solutions of aluminium and gallium nitrates were prepared from the dissolution of the solid salts in water following by the adjustment of the $\mathrm{pH}$ value by using a solution of the diluted nitric acid adjusted to 3 . The solidstate compounds were prepared by mixing with continuous stirring, the solution of the ligand with the respective metal nitrate solution until total precipitation of the metallic (III) pyruvates. The precipitates were washed with distilled water until elimination of the nitrate ions filtered through and dried on Whatman $n^{\circ} 42$ filter paper, and kept in a desiccator over anhydrous calcium chloride.

In the solid-state compounds, the water, ligand and metallic contents were determined from the TG curves.

$\mathrm{X}$-ray powder patters were obtained by using a Siemens D-500 X-ray diffractometer, employing $\mathrm{CuK} \alpha$ radiation $(\lambda=1.541 \AA)$ and settings of $40 \mathrm{kV}$ and $20 \mathrm{~mA}$. Infrared spectra for 2Cl-BP (sodium salt) as well as for the Al, Ga, In and Sc compounds, were run on a Nicolet mod. Impact 400 FT-IR instrument, within $4000-400 \mathrm{~cm}^{-}$ 1 range. The solid samples were pressed into $\mathrm{KBr}$ pellets.

Simultaneous TG-DTA curves, were recorded on a model SDT 2960 thermal analysis system from TA Instruments. The purge gas was an air flow of $100 \mathrm{~mL}$ min-1. A heating rate of

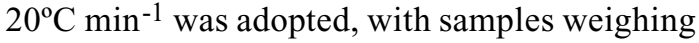
about $7 \mathrm{mg}$. Alumina crucibles were used for recording the TG-DTA curves.

\section{Results and discussion}

The thermoanalytical data of the synthesized compounds are shown in Table 1. These results permitted to establish the stoichiometry of the compounds which is in agreement with the general formula $\mathrm{M}(2-\mathrm{Cl}-\mathrm{BP}) 3 \cdot \mathrm{nH}_{2} \mathrm{O}$, where $\mathrm{M}$ represents $\mathrm{Al}, \mathrm{Ga}$, In, $\mathrm{Sc}$; 2-Cl-BP is 2chlorobenzylidenepyruvate and $n=2,2,1.5$ and 2.5 , respectively.

\begin{tabular}{|c|c|c|c|c|c|c|}
\hline \multirow{2}{*}{ Compounds } & \multicolumn{2}{|c|}{ Metal (\%) } & \multicolumn{2}{c|}{ Ligand loss (\%) } & \multicolumn{2}{c|}{ Water $(\%)$} \\
\cline { 2 - 7 } & Calcd. & TG & Calcd. & TG & Calcd. & TG \\
\hline $\mathrm{Al}(2-\mathrm{Cl}-\mathrm{BP})_{3} .2 \mathrm{H}_{2} \mathrm{O}$ & 3.90 & 3.73 & 87.42 & 87.86 & 5.21 & 5.10 \\
$\mathrm{Ga}(2-\mathrm{Cl}-\mathrm{BP})_{3} .2 \mathrm{H}_{2} \mathrm{O}$ & 9.49 & 9.44 & 82.34 & 82.55 & 4.91 & 4.76 \\
$\mathrm{~h}(2-\mathrm{Cl}-\mathrm{BP})_{3} .1 .5 \mathrm{H}_{2} \mathrm{O}$ & 14.90 & 15.03 & 78.48 & 78.20 & 3.51 & 3.62 \\
$\mathrm{Sc}(2-\mathrm{Cl}-\mathrm{BP})_{3} .2 .5 \mathrm{H}_{2} \mathrm{O}$ & 6.25 & 6.27 & 84.14 & 84.23 & 6.27 & 6.17 \\
\hline
\end{tabular}

Key: 2-Cl-BP is 2-chlorobenzylidenepyruvate

Table 1: Thermoanalytical data of the compound M (2Cl-BP) $3 \cdot \mathrm{nH}_{2} \mathrm{O}$.

The X-ray powder patterns showed that all the compounds were obtained in amorphous state. The amorphous state is undoubledly related to the low solubity of these compounds, as already observed for compounds with other phenylsubstituted derivate of BP $[8,13]$.

Main IR data on the sodium 2chlorobenzylidenepyruvate and its compounds with the metal ions considered in this work are shown in table 2.

From the bands observed for 2-Cl-BP (sodium salt) one centered at $1686 \mathrm{~cm}^{-1}$ (ketonic carbonyl stretching) and another at $1618 \mathrm{~cm}^{-1}$ (antisymetrical carboxilate vibration) it is only the antisymmetrical carboxilate vibration that is shifted to lower frequencies in the compounds, namely 1590$1608 \mathrm{~cm}^{-1}$, suggesting that the binding between the metal and the ligand occurs via the oxygen atom of the carboxilate group without participation of the oxigen atom of the $\alpha$-ketonic carbonyl group.

\begin{tabular}{|c|c|c|c|}
\hline Compounds & $v_{\mathrm{a3}} \operatorname{COO}\left(\mathrm{cm}^{2}\right)$ & $v_{\mathrm{s}, \mathrm{m}} \mathrm{COO}^{-}\left(\mathrm{cm}^{-1}\right)$ & $\vee C=0$ \\
\hline $\mathrm{Na}(2-\mathrm{Cl}-\mathrm{BP}), 0,5 \mathrm{H}_{2} \mathrm{O}$ & 1618 & $140 I_{\mathrm{s}}$ & $1686_{\mathrm{s}}$ \\
\hline $\mathrm{Al}(2-\mathrm{Cl}-\mathrm{HP})_{3}, 2 \mathrm{I}_{2} \mathrm{O}$ & 1608 & $1441_{m}$ & 1759 \\
\hline $\mathrm{Ga}\left(2-\mathrm{Cl}-\mathrm{BP} h_{2} \cdot 2 \mathrm{H}_{2} \mathrm{O}\right)$ & $1590_{5}$ & $1439 \mathrm{~m}$ & $1767 \mathrm{~s}$ \\
\hline $\mathrm{In}\left(2-\mathrm{C}^{\prime}-\mathrm{BP}_{3}\right)_{3},{ }_{3}, 5 \mathrm{H}_{2} \mathrm{O}$ & $1599_{8}$ & $1433_{u 1}$ & 1765 \\
\hline $\mathrm{Se}(2-\mathrm{Cl}-\mathrm{BP})_{3}, 2, \mathrm{SH}_{2} \mathrm{O}$ & $1595_{\mathrm{s}}$ & $1437_{\mathrm{m}}$ & 1765 \\
\hline
\end{tabular}

Table 2: Main IR data for sodium and trivalent metallic 2-chrolobenzylidenepyruvates

$\mathrm{s}$ : strong, m: medium, nsy COO- and nas COO-: symmetrical and anti-symmetrical vibrations of the COO-group, respectively.

The simultaneous TG-DTA and TG/DTG curves of the synthesized compounds are shown in figures 1-4. In all TG-DTA curves the first mass loss corresponding to the endothermic peak is due to the to the loss of hydration water, which occurs in a single step. Immediately after the dehydration the TG curves indicate mass losses in two or three consecutive and/or overlapping steps, however the DTG curves show that the thermal decomposition 
occurs with a large number of steps and through a more complex pathway than that observed from the TG curves.

For the aluminium compound the TG-DTA curves Figure 1, show that the thermal decomposition occurs in three steps between 30 and $600^{\circ} \mathrm{C}$. The first mass loss that occurs up to $140^{\circ} \mathrm{C}$, corresponding to the endothermic peak at $110^{\circ} \mathrm{C}$ is due to the loss of $2 \mathrm{H}_{2} \mathrm{O}($ Calcd. $=5.21 \%$; $\mathrm{TG}=5.10 \%)$. The thermal decomposition of the anhydrous compound occurs in two steps between $140-430^{\circ} \mathrm{C}$ and $430-600^{\circ} \mathrm{C}$, corresponding to the exotherm $(280$ $\left.400^{\circ} \mathrm{C}\right)$ and exothermic peak $\left(555^{\circ} \mathrm{C}\right)$, with loss of $43.78 \%$ and $44.08 \%$, respectively. The total mass loss up to $600^{\circ} \mathrm{C}$ is in agreement with formation of $\mathrm{Al}_{2} \mathrm{O}_{3}$, as final residue $($ Calcd. $=92.63 \%$; $\mathrm{TG}=$ 92.96\%).
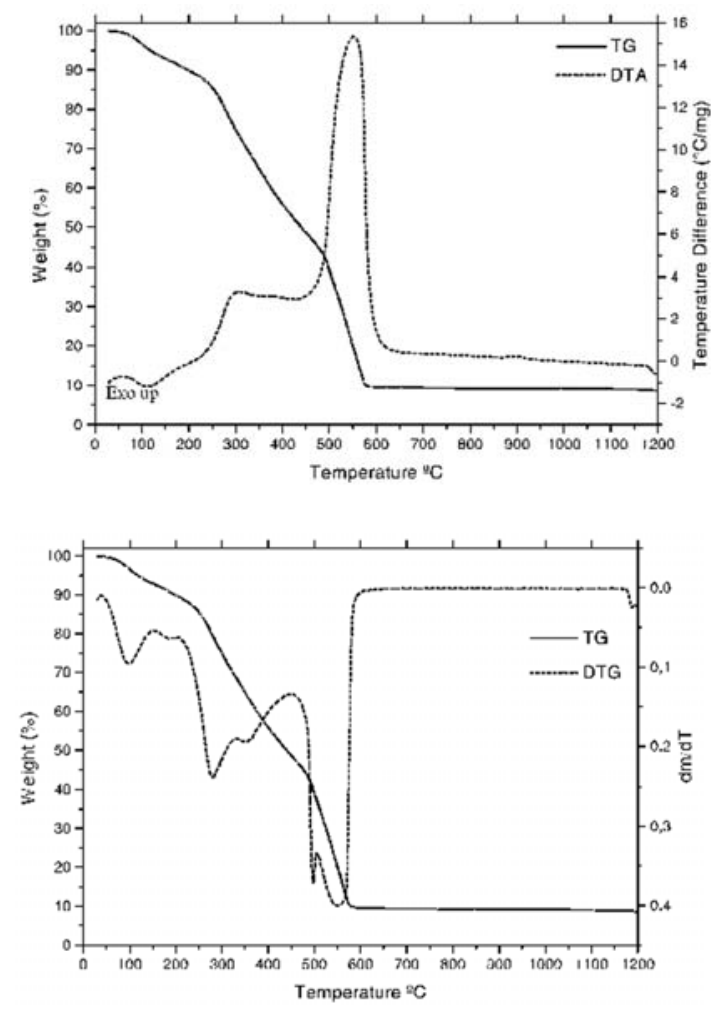

Figure 1. TG-DTA and TG/DTG curves of $\mathrm{Al}(2$ Cl-BP) ${ }_{3} \mathrm{H}_{2} \mathrm{O}$, (crucible $=\mathrm{Al}_{2} \mathrm{O}_{3}$, purge gas: air $100 \mathrm{~mL}$ $\mathrm{min}^{-1}$, heating rate: $20^{\circ} \mathrm{C} \mathrm{min}^{-1}, \mathrm{~m}=7.043 \mathrm{mg}$ ).

For the gallium compound the TG-DTA curves, Figure 2, show mass losses between 40 and $600^{\circ} \mathrm{C}$. The first mass loss up to $130^{\circ} \mathrm{C}$, correspond- ing to the endothermic peak at $100^{\circ} \mathrm{C}$ is due to the loss of $2 \mathrm{H}_{2} \mathrm{O}$ of hidration water (Calcd. $=4.91 \%$; $\mathrm{TG}=4.76 \%$ ). The thermal decomposition of the anhydrous compound occurs in two steps between $130-400^{\circ} \mathrm{C}$ and $400-600^{\circ} \mathrm{C}$, corresponding to the exothermic peaks at $310^{\circ} \mathrm{C}$ and $590^{\circ} \mathrm{C}$, with loss of $42.06 \%$ and $40.49 \%$, respectively. The total mass loss up to $600^{\circ} \mathrm{C}$ is in agreement with formation of $\mathrm{Ga}_{2} \mathrm{O}_{3}$, as final residue (Calcd. $=87.25 \%$; $\mathrm{TG}=$ $87.31 \%)$.
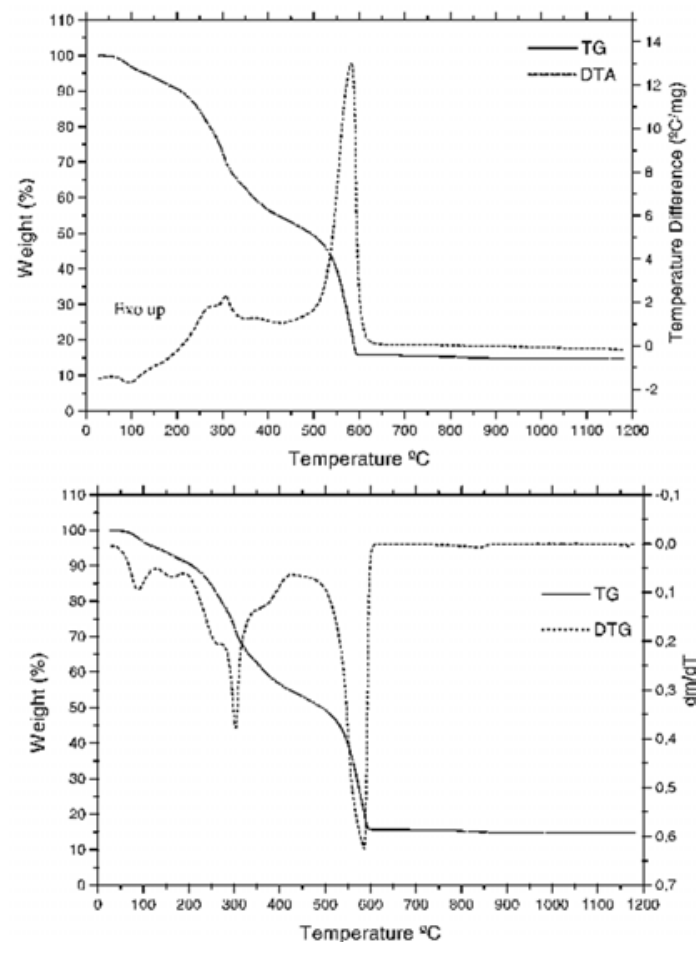

Figure 2 . TG-DTA and TG/DTG curves of Ga(2Cl-BP) $3.2 \mathrm{H}_{2} \mathrm{O}$, (crucible $=\mathrm{Al}_{2} \mathrm{O}_{3}$, purge gas: air $100 \mathrm{~mL}$ $\mathrm{min}^{-1}$, heating rate: $20^{\circ} \mathrm{C} \mathrm{m^{-1 }}, \mathrm{m}=7.021 \mathrm{mg}$ ).

For the indium compound the TG-DTA curves Figure 3, show mass losses between 40$620^{\circ} \mathrm{C}$. The first mass loss up to $130^{\circ} \mathrm{C}$, corresponding to the endothermic peak at $90^{\circ} \mathrm{C}$ is attributed to the dehydration with loss of $1.5 \mathrm{H}_{2} \mathrm{O}$ (Calcd. = $3.51 \%$; $\mathrm{TG}=3.62 \%$ ). The thermal decomposition of the anhydrous compound occurs in two steps between $130-400^{\circ} \mathrm{C}$ and $400-620^{\circ} \mathrm{C}$, corresponding to the exothermic peaks at $320^{\circ} \mathrm{C}$ and $580^{\circ} \mathrm{C}$, with loss of $38.34 \%$ and $39.86 \%$, respectively. The total mass loss up to $620^{\circ} \mathrm{C}$ is in agreement with formation of 
$\mathrm{In}_{2} \mathrm{O}_{3}$, as final residue $($ Calcd. $=81.99 \% ; \mathrm{TG}=$ $81.82 \%)$.
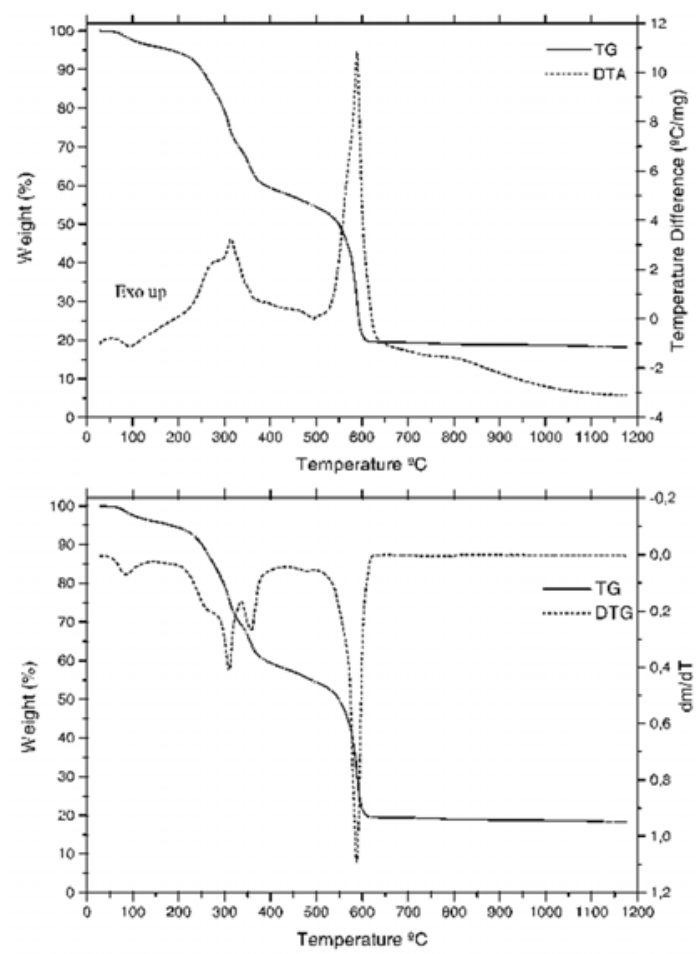

Figure 3. TG-DTA and TG/DTG curves of In(2Cl-BP) $3.1 .5 \mathrm{H}_{2} \mathrm{O}$, (crucible $=\mathrm{Al}_{2} \mathrm{O}_{3}$, purge gas: air $100 \mathrm{~mL}$ $\mathrm{min}^{-1}$, heating rate: $20^{\circ} \mathrm{C} \mathrm{min}^{-1}, \mathrm{~m}=7.542 \mathrm{mg}$ ).

In the scandium compound the TGDTA curves, Figure 4, show mass loss between 40 and $540^{\circ} \mathrm{C}$. The first mass loss up to $140^{\circ} \mathrm{C}$, corresponding to the endothermic peak at $100^{\circ} \mathrm{C}$ is ascribed to the dehydration with loss of $2.5 \mathrm{H}_{2} \mathrm{O}$ (Calcd. $=6.27 \%$; $\mathrm{TG}=6.17 \%$ ). The thermal decomposition of the anhydrous compound occurs in two steps between 140$460^{\circ} \mathrm{C}$ and $460-540^{\circ} \mathrm{C}$, corresponding to the exothermic peaks at $287^{\circ} \mathrm{C}$ and $510^{\circ} \mathrm{C}$, with loss of $52.54 \%$ and $31.69 \%$, respectively. The total mass loss up to $540^{\circ} \mathrm{C}$ is in agreement with formation of $\mathrm{Sc}_{2} \mathrm{O}_{3}$, as final residue (Calcd. $=$ $90.41 \%$; $\mathrm{TG}=90.40 \%$ ).
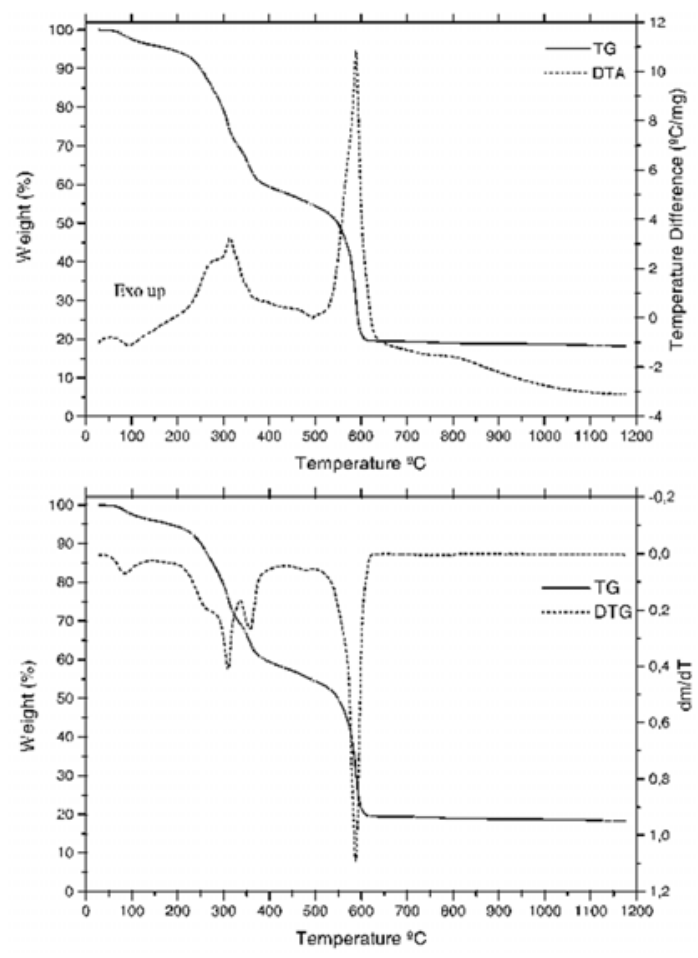

Figure 4. TG-DTA and TG/DTG curves of $\mathrm{Sc}(2-$ Cl-BP) $)_{3} \cdot 2.5 \mathrm{H}_{2} \mathrm{O}$, (crucible $=\mathrm{Al}_{2} \mathrm{O}_{3}$, purge gas: air $100 \mathrm{~mL}$ $\mathrm{min}^{-1}$, heating rate: $20^{\circ} \mathrm{C} \mathrm{min}^{-1}, \mathrm{~m}=6.949 \mathrm{mg}$ ).

\section{Conclusions}

From TG curves, a general formula could be established for these compounds in the solid state.

The TG-DTA curves, X-ray powder patterns and infrared spectroscopic data provided previously unreported information concerning these compounds in the solid state.

\section{ACKNOWLEDGEMENTS}

The authors are grateful to FAPESP (Proc. 97/12646-8) and CNPq for financial support.

BANNACH, G., SCHNITZLER, E., IONASHIRO, M. Síntese, caracterização e comportamento térmico dos compostos 2-clorobenzalpiruvatos de alumínio, gálio, índio e escândio, no estado sólido. 


\section{Resumo}

Foram preparados compostos sólidos $\mathrm{M}(2-\mathrm{Cl}-\mathrm{BP})_{3} \cdot \mathrm{nH} 2 \mathrm{O}$, onde 2-Cl-BP é o ânion 2clorobenzalpiruvato e $\mathrm{M}$ representa os íons metálicos trivalentes: alumínio, gálio, índio e escândio. Esses compostos foram caracterizados e estudados utilizando-se as técnicas de difração de raios $\mathrm{X}$, pelo método do pó, espectroscopia de absorção na região do infravermelho e termogravimetria-análise térmica diferencial simultâneas (TG-DTA). Os resultados permitiram obter informações com respeito a estequiometria, cristalinidade, estabilidade e decomposição térmica.

Palavras-chave: 2-clorobenzalpiruvato, caracterização, comportamento térmico.

\section{References}

[1] COSTA, W.; SCHNitzler, E.; Melios, C. B.; IONASHIRO, M. Preparation and thermal studies of solid state compounds of phenyl substituted derivatives of benzylidenepyruvate and cynnamylidenepyruvate with aluminium, gallium indium and acandium. An. Assoc. Bras, Quím., v. 49, p. 147-153, 2000.

[2] KINNUNEN, J.; WENNERSTRAND, B. Some further applications of xylenol orange as an indicator in the EDTA titration. Chem. Anal., v. 46 p. 92-93, 1957.

[3] KORBL, J.; PRIBIL. R. Xylenol orange: new indicator for the EDTA titration Chem. Anal. v. 46, p. 102-103, 1956.

[4] LELES, M. I. G.; SCHINITZLER, E.; CARVALHO FILHO, M. A. S.; FERNANDES, N. S.; MELIOS, C. B.; IONASHIRO, M. Preparation and thermal decomposition of solid state compounds of 4dimethylaminocinnamylidenepyruvate with trivalent lanthanides and yttrium. An.. Assoc. Bras. Quim., v. 48, p. 3742, 1999.

[5] MARQUES, R. N.; MELIOS, C. B.; PEREIRA, N. C. S.; SIQUEIRA, O. S.; MORAES, M.; MOLINA, M.; IONASHIRO, M. Complexation of some trivalent lanthanides, scandium (III) and thorium (IV) by benzyllidenepyruvates in aqueous solution. J. Alloys Compd., v. 249, p. 102-105, 1997.

[6] Melios, C. B.; CAMPOS, J. T.; MAZZEU, S. M. A. C.; CAMPOS, L.; MOLINA, M.; TOGNOLLI, J. O. Complexation of trivalent lanthanides and yttryum by benzylidenepyruvates in aqueous-solution. Inorg. Chim. Acta, v. 139, n. 1-2, p. 163-164, 1987.
[7] MELIOS, C. B.; IONASHIRO, M.; REDIGOLO, H.; MIYANO, M. H. Complexation of trivalent lanthanides and other metal - ions by 4-methoxibezylidenepyruvate, in aqueous-solution. Eur. J. Solid State Inorg. Chem., v. 28, p. 291-294, 1991.

[8] MIYANO, M. H.; MELIOS, C. B.; RIBEIRO, C. A.; REDIGOLO, H.; IONASHIRO, M. The preparation and thermal decomposition of solid state compounds of 4dimethylaminobenzylidenepyruvate and trivalent lanthanides and yttrium. Thermochim Acta., v. 221, p. 53-62, 1993.

[9] OLIVEIRA, L. C. S.; MELIOS, C. B.; CRESPI, M. S.; RIBEIRO, C. A.; IONASHIRO, M. Preparation and thermal decomposition of solid state compounds of 4methoxybenzylidenepyruvate and trivalent lanthanides and yttrium. Thermochim. Acta, v. 219, p. 215-224, 1993.

[10] OLIVEIRA, L. C. S.; RASERA, D. E.; SIQUEIRA, O. S.; MATOS, J. R.; MELIOS, C. B.; IONASHIRO, M. Preparation and thermal decomposition of solid state compounds of 4 methoxybenzylidenepyruvate with alkali earth metals, except, beryllium and radium. Thermochim. Acta, v. 275, p. 269-278, 1996.

[11] OLIVEIRA, J. D. S.; LELES, M. I. G.; D’ ASSUNÇÃO, L.M.; MELIOS, C. B.; IONASHIRO, M. Thermal behaviour studies of solid state lanthanides (III) and yttrium (III) compounds of cinnamylidenepyruvic acid in an atmosphere of air. J. Braz. Chem. Soc., v. 10, n. 3, p. 209-213, 1999.

[12] PEREIRA, N. C. S.; MELIOS, C. B.; MARQUES, R. N.; SIQUEIRA, O. S.; MORAES, M.; MOLINA, M.; IONASHIRO, M. 4-Dimethylaminocinnamylidenepyruvic acid: Synthesis, characterization and complexation with trivalent lanthanides, yttrium (III), scandium (III), Thorium (IV) and uranium (VI) in aqueous solution. J. Allovs Compd., v. 249, p. $94-98,1997$.

[13] RASERA, D. E.; OLIVEIRA, L. C. S.; MELIOS C. B.; IONASHIRO, M. The preparation and thermal decomposition of some metal compounds of 4cimethylaminobenzylidenepyruvate in the solid state. Thermochim. Acta, v. 250, p. 151-163, 1995.

[14] REIMER, M.; KAMERLING, H. H. Addition reaction of unsaturated alpha - ketonic acids. J. Amer. Chem. Soc., v. 48, p. 2454-2462, 1926.

[15] SCHNITZLER, E.; MELIOS, C. B.; IONASHIRO, M. Preparation and solid state compounds of 4methoxibenzylidenepyruvate and 4dimethylaminocynnamylidenepyruvate with iron (III) and chromium (III). An. Assoc .Bras. Quím.,v. 47, p.326-329, 1998.

[16] SCHNITZLER, E.; MELIOS, C. B.; LELES, M. I.; IONASHIRO, M. Thermal behavior studies of solid state compounds of 4-dimethylaminocynamylidenepyruvate with alkali earth metals, except beryllium and radium. Ecl. Quim., v. 25, p.31-39, 2000. 
[17] SIQUEIRA, O. S.; MELIOS, C. B.; IONASHIRO, M.; MORAES, M.; MOLINA, M. Complexation of some trivalent lanthanides, scandium (III) and thorium (IV) by benzylidenepyruvate in aqueous solution. J. Alloys Compd., v. 225 , p. $267-270,1995$. 